\title{
Imposing Liability on Drug Testing Laboratories for "False Positives": Getting Around Privity
}

\author{
Karen Manfield $\dagger$
}

Many employers today require that prospective or current employees submit to drug testing as a condition of employment. ${ }^{1}$ Although public policy favors a drug-free workplace, ${ }^{2}$ drug testing of workers faces criticism because it may violate a worker's privacy, ${ }^{3}$ because it reflects drug use off the job that may not impair the worker's ability to do her job, ${ }^{4}$ and because the procedure may cause unnecessary emotional distress. ${ }^{5}$ In addition to these

$\dagger$ B.A. 1994, Claremont McKenna College; J.D. Candidate 1997, The University of Chicago.

'A recent American Management Association ("AMA") survey shows that 87.2 percent of its member firms have drug testing programs; the AMA consists primarily of larger companies, but its results suggest that more than a third of all newly hired individuals in 1994 will undergo drug testing. Bob Condor, More Jobs Are Hanging On DrugTest Results: About 33\% of New Hires Can Expect to Be Checked, Study Says, Chi Trib C1 (Apr 11, 1994). In addition, a recent study found that 90 percent of Fortune 1000 companies have drug testing programs. The Week In Healthcare, Modern Healthcare 36 (Aug 3, 1992). The Bureau of Labor Statistics reports that 67 percent of companies with five thousand or more workers have implemented drug testing. Rob Brookler, Industry Standards in Workplace Drug Testing, Personnel J 128 (Apr 1992). However, the numbers are probably lower for smaller companies; a 1989 Bureau of Labor Statistics study found that only 20 percent of workers are employed by companies with drug testing programs. US Dept of Labor, Survey of Employer Anti-Drug Programs, 760 (BLS 1989), cited in Craig Zwerling, James Ryan, and Endel John Orav, The Efficacy of Preemployment Drug Screening for Marijuana and Cocaine in Predicting Employment Outcome, 264 JAMA 2639 (1990). Since only 20 percent of all workers are employed by companies with drug testing programs, and since 33 to 90 percent of all large employers test, the statistics suggest that drug testing is being used primarily by large employers.

2 The National Institute on Drug Abuse ("NIDA") estimates costs of drug use as high as sixty billion dollars. Ira A. Lipman, Fight Drugs With Workplace Tests, NY Times sec 3 at 15 (July 18, 1993). These costs result in part from the increased likelihood of tardiness, absenteeism, and workplace injury typical of recreational drug users. Id. Workers as well as employers favor drug testing because it facilitates a safer workplace; one study found that 97 percent of workers polled believe that drug testing is appropriate, and 26 percent consider it a necessity. Id. See also Andrew E. Floren, Urine Drug Screening and the Family Physician, Am Family Physician 1441 (May 1994).

${ }_{3}$ See, for example, Judith Wagner DeCew, Drug Testing: Balancing Privacy and Public Safety, 24 Hastings Ctr Rpt 17 (Mar-Apr 1994).

- In one case, a woman tested positive who had used marijuana three months earlier at a party. Chris Spolar, Electronics Technician, Montana: Did Two Puffs Cut Short a New Career?, Wash Post A14 (Dec 6, 1988). No test can determine whether a worker has been under the influence of drugs while at work.

' Charles J. Dangelo, Comment, The Individual Worker and Drug Testing: Tort Ac- 
problems, drug testing may result in a "false positive," which occurs when a test yields a positive test result even though the worker has not used drugs in the period measured by the test. ${ }^{6}$ False positives arise in a small but significant number of cases, yet they can have devastating results for their victims, such as the loss of both current and prospective employment. Defenders of drug testing argue that the majority of workers benefit from a safer and more productive workplace, and that the increased safety and productivity is advantageous to employers. ${ }^{7}$ Even if these claims are correct, however, workers who experience false positives suffer from the absence of adequate safeguards against false positives and from the inability to secure compensation for their injuries.

Over the past decade, a number of victims of false positives have sued the parties responsible for administering the tests because the victims' employment was terminated on the basis of false positive test results. These plaintiffs have found themselves in a legal nowhere land, with no clear remedy and little precedent to guide their legal actions. They have tried a variety of causes of action, ranging from simple negligence to product liability. Most courts have rejected these plaintiffs' claims for product liability, breach of contract, and defamation, but the courts have disagreed about whether a testing laboratory owes a general duty of reasonable care to these workers. ${ }^{8}$

The courts that have addressed the problem of false positives have reached inconsistent holdings, without adequately explaining their results or responding fully to opposing arguments. Courts finding liability have applied a simple negligence standard, using a balancing test to determine whether a duty of care should exist. While the judges in these cases reach the right result, they appear to do so on the basis of their gut reactions to the plight of the plaintiff, while ignoring concerns about efficiency and precedent. Because these courts do not even consider possible objections to their position, the resulting decisions have failed to persuade more skeptical courts that testing laboratories ought to be held liable.

Courts that have refused to find liability have done so in two scenarios. In the first scenario, the plaintiffs asserted claims of

tions for Defamation, Emotional Distress and Invasion of Privacy, 28 Duquesne L Rev $545,546(1990)$.

${ }^{6}$ See notes 16-19 and accompanying text.

' See, for example, Kathy O'Brien, Drug Testing Can Save Companies Money in the Long Run, Bus Dateline 1 (Jan 1, 1996).

${ }^{8}$ See notes 45-48 and accompanying text and notes 92-97 and accompanying text. 
product liability, breach of contract, defamation, or intentional tort. Courts have rejected these claims on the ground that the service provided by the laboratory is not a "product," and that the laboratory's misconduct was not intentional. In the second and more troubling scenario, courts presented with a negligence claim have held that, because the harm involved was purely economic or emotional, the plaintiff must prove intentional misconduct on the part of the laboratory in order to recover. In these cases, plaintiffs who made the same type of simple negligence claims that were successful in other courts did not recover.

This Comment argues that courts denying liability get it wrong. While their conclusions find some support in traditional tort and contract principles, those principles are based on concerns about unlimited liability that do not apply in the context of false positive test results. Accountants' liability presents a stronger analogy and demonstrates that physical harm need not always be present for courts to impose liability for unintentional misconduct. Part I of this Comment explains why employees should have a remedy against testing laboratories. The argument is based in part on the optimal incentives such a duty would create for laboratories, and in part on the sad fact that, without some means to recover against the laboratory, a wronged worker may have no remedy for the injuries caused by a false positive test result. Part II describes the conflict in existing case law regarding whether such a duty of care exists. Part III explores the courts' treatment of accountants' liability for insight into how courts have dealt with negligent infliction of emotional distress and economic harm. Finally, the Comment concludes that the common law presumption against recovery for purely economic loss should not apply in this context, and that fairness and efficiency require imposing a duty of care to workers on drug testing laboratories. ${ }^{9}$

\section{WHY LIABILITY FOR TESTING LABORATORIES IS APPROPRIATE}

This Part explains why workers should have a remedy against drug testing laboratories that fail to exercise reasonable care. First, it provides an overview of the drug testing process. Next, it shows how the existence of a duty would lead to optimal incentives for the laboratories. Finally, it explains why many

3 Of course, academics continue to debate the goals of tort law, including when compensation is required and the relative importance of compensation and efficiency. See Richard A. Epstein, Cases and Materials on Torts xxxi (Little, Brown 5th ed 1990). In this case, the goals of compensation and efficiency do not conflict. 
workers will have no remedy if they cannot successfully sue the laboratories that negligently perform drug tests.

\section{A. An Overview of the Drug Testing Process}

Drug testing usually involves urinalysis, a procedure in which a worker's urine sample is analyzed for the presence of drugs. ${ }^{10}$ The substances tested for may vary, but the National Institute on Drug Abuse, which regulates drug testing of federal workers and provides a benchmark for the testing of private workers, focuses on five drug classes: marijuana, cocaine, opiates (morphine and codeine), phencyclidine (PCP), and amphetamines (amphetamine and methamphetamine). ${ }^{11}$ In addition, some private employers and state regulators require testing for barbiturates, benzodiazepines (diazepam or Valium, and oxazepam or Serax), LSD, methaqualone (quaaludes), and propoxyphene (Darvon). ${ }^{12}$

Of the many testing procedures currently available, only one method, gas chromatography/mass spectrometry ("gas chromatography"), can positively identify the existence of a particular illegal substance in the urine. ${ }^{13}$ That procedure requires expert administration in controlled clinical conditions and is considerably more expensive than the cheapest testing method. ${ }^{14}$

Most worker testing programs use the cheaper immunoassay methods for an initial screening. ${ }^{15}$ These methods do not test for the presence of particular drugs in the urine, but for their metabolites, the chemicals produced when a drug enters the digestive system. These tests are inherently overinclusive because they detect metabolites with properties similar to the metabolites of the drugs for which they are testing. ${ }^{16}$ For example, immuno1992)

${ }^{20}$ Mark D. Uhrich, Are You Positive the Test Is Positive?, HRMagazine 44, 45-46 (Apr

11 Id at 46.

${ }^{12}$ Id.

${ }^{13}$ Gary Lee, The Highly Refined Science of Testing For Possible Drug Use: Results Are Rarely Erroneous, Specialists Say, Wash Post A10 (June 27, 1995).

${ }^{14}$ Gas chromatography technicians must have a master's degree or a doctorate. Milt Freudenheim, Booming Business: Drug Use Tests, NY Times D1, D2 (Jan 3, 1990). Cheap testing methods such as on-site immunoassay tests can cost as little as \$7. In contrast, confirmatory gas chromatography tests cost from $\$ 100-\$ 150$. Edward A. Ward, Employee Drug Testing: Aalberts and Walker Revisited, J Sm Bus Mgmt 77 (Jan 1991).

${ }^{15}$ Uhrich, HRMagazine at 46 (cited in note 10).

"An immunoassay test is "not highly specific-it may mistake one drug for another." Lee, Wash Post at AIO (cited in note 13). "The screening test, called the EMIT or enzyme multiplied immunoassay test, has been shown to give false positives because of 'cross reactivity" to substances such as Sudafed. Jeanne Jackson, Drug screening placed on trial in Belmar case, Asbury Park Press AAl, AA3 (July 9, 1995). 
assay tests may mistake an over-the-counter cough medicine containing pseudoephedrine for illegal amphetamines. ${ }^{17}$ Manufacturers of the drug tests claim that these tests are accurate in 95 to 97 percent of all cases, but some studies show that in practice the tests yield incorrect results in 25 to 60 percent of the cases. ${ }^{18}$ As in the case of gas chromatography, the immunoassay methods require expertise in administering the test, and the differential between the manufacturer's predicted error rate and the rate that occurs in practice probably results from improper testing procedures. ${ }^{19}$

Given the wide range of testing methods available and the degree of skill required to administer these tests, testing laboratories can do much to control, and therefore lower, the number of false positives. By carefully selecting initial testing methods, by deciding whether to retest positive results, and by investing in worker training and supervision, testing labs can choose among different degrees of accuracy. Assuming that, as in the typical case, the laboratory uses a less accurate method for initial screenings, laboratories can also choose whether to use a more accurate method to retest negative results, positive results, or both. Even if laboratories retest positive results, subtle errors in favor of false positives may remain.

Furthermore, the testing laboratory's choices about retesting methods can greatly influence the likelihood that false positives will be eliminated. If the laboratory retests using the same immunoassay method it uses for the initial screening, a substantial number of false positives will remain, partly because of the immunoassay's inaccuracy, and partly because a subject may continue to use substances with metabolites similar to those of an illegal drug. ${ }^{20}$ In contrast, retesting positive results with the

${ }^{17}$ Lee, Wash Post at A10 (cited in note 13).

1" Jennifer Harris, Testing the Drug-Abuse Waters, Advantage 26 (Apr 1, 1988). See also Ward, J Sm Bus Mgmt at 77 (cited in note 14), citing R.J. Aalberts and J.L. Walker, Worker Drug Testing: What the Small Firm Owner Needs to Know, J Sm Bus Mgmt 53 (Oct 1988) (Aalberts and Walker found false positive rates of 5 to 20 percent, but other studies show overall error rates of 25 to 97 percent.).

19 "While forensic scientists say the tests are very precise if done correctly, they admit that human error can lead to inaccurate results." Jackson, Asbury Park Press at AA1, AA3 (cited in note 16). "Far and away the primary cause of false results is human error. Samples that are handled carelessly, information entered incorrectly, or techniques not followed precisely can all contribute to error." Uhrich, HRMagazine at 47 (cited in note 10).

21 These substances may include poppy seeds, antihistamines, ibuprofen, cold medicines, certain arthritis medicines, foreign-made vitamin formulations, topical application of cocaine during surgery, and "passive inhalation" of crack cocaine or marijuana smoke. See James L. Abelson, Letter to the Editor, Urine Drug Testing-Watch What You Eat!, 266 JAMA 3130 (1991) (poppy seeds); Condor, Chi Trib at C2 (cited in note 1) (ibuprofen, 
more expensive and accurate gas chromatography test, properly administered, would eliminate virtually all the false positives. ${ }^{21}$ Of course, the proper administration of drug tests requires not only scientific expertise, but also tight security in order to avoid tampering by laboratory workers or outsiders, and the maintenance of detailed records to prove that the specimen has not left the laboratory's "chain of custody."22

In these ways, laboratories can control the number of false positives produced during drug testing. Creating the incentives to exercise that control can have a significant impact on the number of false positive results. But, in the absence of pressure from the employers who contract with laboratories to test workers, or from the workers whom they test, laboratories need not consider the costs of false positives when deciding exactly what procedures to use and how much money to spend on precautions.

\section{B. Optimal Care Requires that Laboratories Consider Workers' Preferences as well as Employers'}

The level of care that a testing laboratory exercises in purchasing and maintaining equipment, training laboratory workers, and conducting tests influences the number of false positive test results that are likely to occur. The "optimal" number of false positives is the number at which the group of people potentially affected by false positives would not want the laboratory to invest its resources differently, assuming the laboratory could pass its costs on to those affected by its level of care. At the optimal level of care, the group of affected persons, which includes both employers and workers, would not want to pay the addi-

poppy seeds, prescription cough medicine, antihistamines); Marie Pulinio, et al, Letter to the Editor, False-positive Benzodiazepine Urine Test Due to Oaxprozin, 273 JAMA 1905 (1995) (arthritis medicines); M. Joseph Fedoruk and Loretta Lee, Positive Preemployment Urine Drug Screen Caused by Foreign-Manufactured Vitamin Formulation, $155 \mathrm{~W} J \mathrm{Jed}$ 663 (1991) (foreign-made vitamin formulations); Oscar A. Cruz, et al, Urine Drug Screening for Cocaine After Lacrimal Surgery, 111 Am J Opthamology 703 (1991) (topical application of cocaine); Teri Randall, Infants, Children Test Positive for Cocaine After Exposure to Second-Hand Crack Smoke, 267 JAMA 1044 (1992) (passive inhalation).

21 An immunoassay test, coupled with a confirmatory gas chromatography test, yields an accuracy rate of over 99 percent. Ward, J Sm Bus Mgmt at 77 (cited in note 14).

2 The chain of custody is a set of procedures used to ensure that the urine sample is actually produced by the worker at the time of the test, and that neither the worker nor any other person has any opportunity to adulterate the urine sample. Each individual who comes in contact with the urine sample must sign and date a form, document, or label that follows the sample as it is taken from the testing site to the laboratory, tested, and stored. Rob Brookler, Industry Standards in Workplace Drug Testing: EQP and Drug Testing, Personnel J 128, 130 (1992); H. Westley Clark, The Role of Physicians as Medical Review Officers in Workplace Drug Testing Programs: In Pursuit of the Last Nanogram, 152 W J Med 514 (1990). 
tional cost required to reduce the number of false positives slightly. At the same time, this group would not choose a higher level of false positives if the laboratory passed on its incremental savings from the less costly methods.

When the entire group's preferences are not considered, the laboratory's level of care will probably deviate from the optimum. Indeed, if only employers' preferences are considered, the number of false positives likely will increase. Since employers generally pay for drug tests, testing laboratories have no reason to consider the preferences of the individual workers they test. Because employers' major concerns are with costs and efficiency, they are likely to request the cheapest possible methods or seek out the cheapest provider of testing services. ${ }^{23}$

Indeed, it is likely that most employers prefer a testing method that yields more false positives than false negatives. This is because the potential costs of keeping a drug abuser in the workplace due to a false negative, with the attendant reputational, motivational, and economic consequences, probably exceeds an employer's cost of finding a replacement for a worker mistakenly terminated on the basis of a false positive. Employers may view the possibility of mistakenly dismissing these workers to be a trivial loss when compared with the risk of continuing to employ drug users, who pose threats of theft, reduced productivity, accidents, absenteeism, and tardiness. ${ }^{24}$ While this assumption might be false in a labor market where workers require substantial education and training, and are therefore difficult to replace, for-cause and random drug testing occurs most often with

\footnotetext{
${ }^{2}$ Of course, in some cases, employers might find more expensive methods in their self-interest because the cost of losing an innocent worker exceeds the marginal cost of the more expensive method, but this is unlikely, assuming that most employers probably test low-level workers instead of professionals in whom the company must invest substantial training.

${ }^{24}$ Wendy D. Farina, The Controversy Continues: Drug Testing, Sec Mgmt 65 (Feb 1990). Assuming that a worker could prove that her test result was false, she might be able to get her job back. However, in most cases, proving the worker's innocence would take time, during which the worker's position probably would be filled. In addition, some employers might view the worker as "damaged goods" and choose to believe the first (positive) result rather than the second; a worker would have no redress for this action.

In addition, proving a false positive requires that the laboratory take the important precautionary measure of "splitting" the worker's sample, testing one and retaining the other so that a second test can be performed to verify the accuracy of the first. Without such a split, a worker cannot prove that the drugs did not simply leave her system between the first test and the second. As a practical matter, courts will probably have to adopt a "res ipsa loquitur" rule with regard to split samples since, otherwise, laboratories could avoid liability by not using them. Split samples are a routine aspect of the two-step immunoassay and gas chromatography testing regimen, so most laboratories should already require them.
} 
low-skilled workers who face greater competition from other workers and receive less training.

Of course, laboratories do not explicitly give employers the option of choosing a testing method that is less costly than the optimal method and that yields more false positives. ${ }^{25}$ But laboratories that are willing to skip expensive double-checking procedures can undercut those that are not, thereby giving employers cheaper testing with the only disadvantage being a higher false positive rate-arguably a result that employers prefer. ${ }^{26}$

Workers, in contrast, would prefer testing methods that minimize false positives. When a false positive occurs, the worker loses the value of her current position and may also face substantially reduced employment prospects for the future. In addition, she may feel considerable distress and public embarrassment at being labeled a drug user. The employer, in contrast, only incurs a one-time expense of firing and replacing the worker. ${ }^{27}$ Thus, because the potential harm to workers from false positives dramatically outweighs that of their employers, the failure to take workers' preferences into account leads to imperfect incentives for drug testing laboratories. ${ }^{28}$

\footnotetext{
${ }^{25}$ Laboratories may also choose the "cutoff level" above which the presence of a substance will be reported as a positive result. "Decisions on choosing cutoffs depend on how many false negatives, false positives, and unconfirmed test results are economically and scientifically acceptable. ... [V]alue judgments may differ." DeCew, 24 Hastings Ctr Rept at 19 (cited in note 3 ).

${ }^{26}$ For example, employers can easily cut corners by dealing with laboratories that are not certified by NIDA. NIDA-certified laboratories must pass stringent tests, so certification provides strong evidence that the laboratory will exercise a high degree of care in order to avoid false positive results. Because laboratories must pay seventeen thousand dollars merely to apply for certification, however, laboratories that forgo the certification can offer services at a lower price-but may also offer less accurate results. David A. Ambruster, A guide to NIDA certification for workplace drug testing, Med Lab Observer 31 (Feb 1992). On average, drug testing for workers subject to federal rules (which include use of a NIDA-certified laboratory) costs ten dollars more per worker than tests for those not so subject. Freudenheim, NY Times at D1 (cited in note 14). A recent AMA study showed that 20 percent of the firms that test for drugs do not use NIDA-certified laboratories for confirming positive results. Condor, Chi Trib at C2 (cited in note 1). Since only 20 to 30 percent of applicants pass NIDA's certification process, however, chances are that a substantial number of non-AMA companies use uncertified laboratories. Brookler, Personnel $J$ at 128 (cited in note 1). According to the Institute for a Drug-Free Workplace, not using a NIDA-approved lab can produce false-positive results at a rate of 2 to 8 percent. Condor, Chi Trib at C2 (cited in note 1).

${ }^{27}$ This is especially true where the employer tests on a for-cause basis, because the benefit to an employer of retaining an employee whose performance has been below par or who has been involved in a workplace accident, but who does not use drugs, is very low. In fact, the employer may be delighted to have a litigation-proof, easily explained justification to fire the worker.

${ }^{23}$ In a perfect market where workers and employers have full information, laboratories will choose the efficient level of care, which includes the effects on workers as well as on employers.
} 
If employers had the right incentives, they could bargain with laboratories for the level of protection that workers want. In theory, workers would be willing to pay employers to choose reliable laboratories. This payment would be reflected in the workers' willingness to accept a lower compensation package than they would otherwise receive. Workers would weigh the marginal loss of job security from less reliable methods with the increase in compensation they could receive by accepting such methods.

Several problems limit the effectiveness of this solution. First, few workers will have enough information about the relative reliability of drug testing laboratories, and their individual chances of receiving a false positive result, to make this calculation. Second, asking the potential employer about its drug testing program might make a bad impression, since it suggests that the worker may have used drugs. Finally, these negotiations would be based on the reputation of the laboratories an employer might use; this would be likely to change over time and make it difficult to create a useful contractual term between employers and workers.

Unfortunately, in the drug testing context, most employers do not have an adequate incentive to take workers' preferences into account. Most employers cannot be held liable for failing to protect workers against false positives. The false positive may cause an unreasonable termination of the worker, but the doctrine of employment-at-will protects employers from suits for unreasonable termination absent certain narrow exceptions that will not apply in this context. ${ }^{29}$

Even if employers were held liable, and therefore had to take workers' preferences into account, this would not be as effective as holding laboratories liable. After all, employers have only indirect control over the precautions taken. ${ }^{30}$ Employers can hire

${ }^{2}$ See Part IIB. In other contexts, employers are forced to consider workers' preferences because they face legal liability for harms to workers. Hostile environment discrimination provides an example of how this occurs: since it is costly to monitor workers' behavior, employers may prefer to risk losing a few workers rather than expend the resources necessary to make the workplace tolerable to everyone. In contrast, workers probably would prefer that the employer make the effort, even if it passed on its costs to workers in the form of lower compensation. Because it is difficult to discover whether a workplace is hostile without actually working in it, workers might have trouble bargaining for the result they prefer. By holding employers liable for hostile environment discrimination, however, the law forces them to consider costs to workers when deciding whether and how much to monitor workplace problems.

${ }^{3}$ If employers were liable, they might have indemnification suits against a negligent laboratory for their errors. However, this would add unnecessary administrative costs compared to simply holding laboratories liable. Innocent employers would face costly litigation, even if the laboratory eventually indemnified them. While this cost would give 
and fire laboratories on the basis of their reputations for safety, and would have an incentive to do so if held liable to workers for termination on the basis of a false positive. But, since laboratories have more direct control over the precautions they take, imposing liability on them directly would achieve better results. Indeed, imposing a duty of reasonable care on drug testing laboratories will lead to optimal testing precautions by correcting the likely bias in favor of false positives that results from considering only employers' preferences. ${ }^{31}$

\section{Recovery Against the Employer is Difficult for the Worker}

Workers often look to their employers for redress when they are terminated on the basis of an allegedly false positive result. Although some workers recover based on exceptions to employment-at-will, many find they are unable to recover their losses. ${ }^{32}$ Plaintiffs sometimes recover for defamation, but this usually requires that an employer communicate the results of a positive test knowing that a subsequent test came up negative. ${ }^{33}$ Similarly, some plaintiffs have recovered for invasion of privacy, but this has succeeded only when the defendant required that the

employers an extra incentive to choose trustworthy laboratories, the additional litigation costs of liability might outweigh any benefit.

${ }^{31}$ This Comment assumes that there is an optimal point at which the excess of benefits over costs for the testing procedures used, taking into account the preferences of all parties immediately involved, is greatest. In a perfectly functioning marketplace, this result could be achieved contractually. In the employment context, however, information failure may prevent the optimal result from occurring contractually.

${ }_{32}$ See, for example, Stein v Davidson Hotel Co, 1996 Tenn App LEXIS 280 (Tenn Ct App) (holding that worker who was terminated after a false positive drug test failed to state a claim against defendant employer). See also Jennings $v$ Minco Technology Labs, Inc, 765 SW2d 497 (Tex App 1989); Satterfield v Lockheed Missiles and Space Co, 617 F Supp 1359 (D SC 1985), cited in Dangelo, Comment, 28 Duquesne L Rev at 548 (cited in note 5). The doctrine of "self-publication" defamation liability, recently recognized by the Minnesota Supreme Court, could be applied in this situation. See Dangelo, Comment, 28 Duquesne $\mathrm{L}$ Rev at 550-51 (cited in note 5). Traditional defamation liability does not apply, because employers' statements about worker drug use within the company are generally protected by a qualified privilege, and employers generally do not convey the information to third parties. In "self-publication" defamation, however, a plaintiff can recover where the plaintiff is "in some way compelled to communicate a defendant's defamatory statement to a third person and it is foreseeable to the defendant that the plaintiff would be so compelled." Id at 552. This could apply to situations in which a worker is fired on the basis of a false positive test result, and must then repeat the results of the test in interviews with prospective employers who inquire about the reason for termination. Id, citing Lewis $v$ Equitable Life Assurance Society, 389 NW2d 876 (Minn 1986).

${ }^{33}$ See, for example, Houston Belt and Terminal Railway Co $v$ Wherry, 548 SW2d 743 (Tex Civ App 1977) (allowing plaintiff to recover from employer who intentionally published results of plaintiff's positive drug test knowing that subsequent test was negative), cited in Dangelo, Comment, 28 Duquesne L Rev at 549 (cited in note 5). 
plaintiff be observed while producing the urine sample. ${ }^{34}$ These causes of action deal with intentional abuse of a worker's privacy, but do not protect the typical worker whose employer has terminated her in good faith on the basis of one or two drug tests.

Some workers may recover against their employers for wrongful termination. However, two factors limit the usefulness of wrongful termination actions for victims of false positive test results. First, a wrongful termination action requires that the employer act "wrongfully," which generally means in violation of public policy. ${ }^{35}$ Thus, since drug testing programs serve important public policy goals, ${ }^{36}$ if an employer relies on the results of the drug test in good faith, it will not be held liable for the termination. ${ }^{37}$

Second, two-thirds of workers today are employees-at-will, ${ }^{38}$ which means their employers can terminate them at any time and for any reason, for just cause or no cause. ${ }^{39}$ Although the doctrine of employment-at-will is circumscribed by certain public policy exceptions, simple unfairness is not one of them. ${ }^{40}$ An implied "just cause" exception to employment-at-will may arise when an employer, through its personnel manual or recruitment promises, has suggested that it will not terminate a worker arbitrarily. ${ }^{41}$ While an implied promise not to terminate on the basis

${ }^{34}$ Kelley v Schlumberger Technology Corp, 849 F2d 41, 43 (1st Cir 1988), cited in Dangelo, Comment, 28 Duquesne $L$ Rev at 553 (cited in note 5).

${ }^{35}$ Dangelo, Comment, 28 Duquesne L Rev at 548 (cited in note 5); Stein, 1996 Tenn App LEXIS 280 at * 10-21.

${ }^{36}$ In holding that an employer's policy of terminating workers based on positive test results did not violate public policy even where the plaintiff alleged that the testing laboratory was negligent, the Stein court pointed out that the policy violated no statute, constitutional provision, or other clear public policy, and that "[t]o the contrary, creating a drug free work environment in the public and private sector is completely consistent with the State of Tennessee's public policy.” 1996 Tenn App LEXIS 280 at *21.

${ }^{37}$ See Adolph M. Koven and Susan L. Smith, Just Cause: The Seven Tests 105 (BNA 2d ed 1992) (" $[A]$ positive test result is cause for discharge or other discipline . ...").

Frances H. Miller, Biological Monitoring: The Employer's Dilemma, $9 \mathrm{Am}$ J L Med 387,423 (1984).

${ }^{3}$ Decew, 24 Hastings Ctr Rpt at 33 (cited in note 3); James N. Dertouzos, The End of Employment-at-Will: Legal and Economic Costs 1 (RAND 1988).

* Those exceptions generally consist of situations in which the worker tries to exercise a right or duty of citizenship, such as refusing to violate a law or reporting her employer's violation, or situations where the employer's conduct gives rise to an implied just cause limitation on the right to terminate. Additionally, most states recognize a public policy exception for worker "whistleblowers" who report an employer's violation of the law or question a perceived violation without reporting it. The law recognizes this duty not simply because the employer has acted unfairly, but because the law must recognize the worker's competing obligations of loyalty to her employer and duty as a citizen to report a crime. See Daniel P. Westman, Whistleblowing: The Law of Retaliatory Discharge 19, 2428 (BNA 1991).

"Ralph H. Baxter, Jr. and Gary R. Siniscalco, Manager's Guide to Lawful Termina- 
of a false positive test result may provide a basis for recovery, careful employers will avoid making such promises.

Finally, workers in a few states are protected by a duty of good faith and fair dealing in employment relationships. However, this duty has generally been applied where an employer's conduct was malicious or otherwise clearly wrongful. ${ }^{42}$ In most situations, an employer will rely on the results of a drug test in good faith because the employer lacks expertise in determining the appropriate level of care for a testing laboratory. While new public policy exceptions to employment-at-will may develop as the modern trend against the at-will rule continues, ${ }^{43}$ for now most workers have difficulty recovering from their employers on the basis of false positive test results. ${ }^{44}$

This Comment argues that holding drug testing laboratories liable for failure to take reasonable precautions against false positives achieves a balance between competing policy concerns by ensuring that the full consequences of false positives will be borne by the party with the greatest control over the accuracy of test results. Because workers cannot recover from their employers, imposing liability on drug testing laboratories would also prevent lack of compensation for workers harmed by false positives.

\section{CASES REGARDING LIABILITY OF LABORATORIES FOR FALSE POSITIVES}

A number of workers have sued laboratories for false positive test results, and have received a mixed reception from the courts. Some courts have analyzed the issue as a question of simple negligence, with the existence of a duty to be determined by a balancing test. These courts have frequently held testing laboratories liable, but for unclear reasons. Other courts have altogether ignored the possibility of a remedy for simple negligence, denying plaintiffs' claims for strict product liability and breach of contract, and converting their claims for simple negligence into torts requiring intentional conduct such as interference with contractual advantage or infliction of emotional distress. As the following discussion demonstrates, the courts hold-

tions 19-23 (Exec Enter 1983); Pine River State Bank v Mettille, 333 NW2d 622 (Minn 1983).

${ }^{42}$ Baxter and Siniscalco, Manager's Guide at 31-35 (cited in note 41).

${ }^{43}$ See generally Dertouzos, The End of Employment-at-Will (cited in note 39).

" Anne M. Rector, Comment, Use and Abuse of Urinalysis Testing in the Workplace: A Proposal for Federal Legislation Limiting Drug Screening, 35 Emory L J 1011, 1028 (1986). 
ing testing laboratories liable did so without fully considering possible objections to imposing liability, while the courts denying liability recognized those objections but did not adequately consider possible replies.

\section{A. Cases Imposing Liability}

Courts in Louisiana and Illinois have held that testing laboratories owe a general duty of care to the subjects of their tests. ${ }^{45}$ Most states determine the existence of a duty of care by applying a multi-factor balancing test. Although the factors vary slightly from state to state, most courts weigh the foreseeability of the injury, the likelihood of the injury, the difficulty of preventing it, and the consequences of placing the burden on the defendant. ${ }^{46}$

Properly applied, this balancing test leads to liability for negligent drug testing laboratories. The injury caused by a false positive result is clearly foreseeable. After all, drug testing laboratories are surely aware that employers may base decisions whether to hire or fire workers on the result of a positive test. This injury is also likely, given the potential for the mishandling of specimens, the failure to retest positive results using the more accurate gas chromatography method, and the failure to explore the possibility of alternative causes for a positive result. ${ }^{47}$ The difficulty of avoiding such an injury is not great, and any costs of

${ }^{4}$ See Elliott $v$ Laboratory Specialists, Inc, 588 S2d 175 (La App 1991); Lewis v Aluminum Co of America, 588 S2d 167 (La App 1991); Nehrenz v Dunn, 598 S2d 915 (La App 1992); Stinson v Physicians Immediate Care, Ltd, 269 Ill App 3d 659, 646 NE2d 930 (1995).

${ }^{45}$ See, for example, Gouge v Central Illinois Public Service Co, 144 Il 2d 535, 582 NE2d 108, 112 (1991), cited in Stinson, 646 NE2d at 933; Ingle v Allen, 71 NC App 20, 321 SE2d 588, 594 (1984); Griggs v BIC Corp, 981 F2d 1429, 1435-36 (3d Cir 1992); Palka $v$ Servicemaster Management Services Corp, 83 NY2d 579, 611 NYS2d 817, 821 (1994); White $v$ Southern California Edison Co, 25 Cal App 4th 442, 30 Cal Rptr 431, 435 (1994); Fetty $v$ Miller, 905 SW2d 296, 301 (Tex App 1995); Coleman v Eddy Potash, Inc, 120 NM 645, 905 P2d 185, 190 (1995); Cram v Howell, 662 NE2d 678, 681 (Ind App 1996); Hill v Charlie Club, Inc, 279 Ill App 3d 754, 665 NE2d 321, 325 (1996); King v King, 922 F Supp 700, 705 (D NH 1996); Carvalho $v$ Toll Brothers and Developers, 143 NJ 565, 675 A2d 209, 212 (1996); Golden Spread Council, Inc v Akins, 926 SW2d 287, 289-90 (Tex 1996); Trask $v$ Butler, 123 Wash 1026, 872 P2d 1080, 1083 (1994).

${ }^{47}$ Both simple negligence and duty to warn claims could be completely preempted by the use of a Medical Review Officer (MRO). An MRO is an independent expert who discusses a positive result with the subject in order to determine whether the result has some explanation other than drug use. This review takes place before the results are transmitted to the employer, thereby protecting the worker's privacy and reputation. Clark, $152 \mathrm{~W} \mathrm{~J}$ Med at 515-16 (cited in note 22). If courts consistently held laboratories liable for failure to warn, laboratories might begin using MROs as standard practice. Currently, this is not standard. Of the firms surveyed by the American Management Association in 1994, fewer than half the firms testing for drugs used an MRO to explore possible causes of positive results. 
doing so can be passed on to the workers who benefit from the care: the laboratory can raise its prices, and employers can offer workers reduced compensation in exchange for the more expensive tests. Finally, the consequence of placing the burden on the testing laboratories is to align the incentives to encourage the avoidance of an injury where the laboratory has the ability to do so.

Four courts applying this balancing test have found liability, although only one court examined each factor of the balancing test. ${ }^{48}$

In the first of these cases, Elliott $v$ Laboratory Specialists, Inc, the Louisiana Court of Appeals upheld a jury verdict of twenty-five thousand dollars against Laboratory Specialists, Inc. ("LSI"), in favor of a worker, David Elliott, who had received a false positive test result. ${ }^{49}$ The court applied a balancing test to determine whether LSI owed Elliott a duty of care, stating that "[t]o suggest that LSI does not owe Elliott a duty to analyze his body fluid in a scientifically reasonable manner is an abuse of fundamental fairness and justice. ${ }^{150}$

Lewis $v$ Aluminum Co of America, decided at about the same time as Elliott, analyzed the issue more thoroughly than the Elliott court, addressing all the factors of the balancing test before assigning liability. ${ }^{51}$ The court began by finding applicable a Louisiana statute that imposes a duty on a tortfeasor to repair damage caused through his negligence, imprudence, or want of skill. ${ }^{52}$ Having thus established that negligence might be appropriate, the court then pointed out that damages were foreseeable and not remote, and that imposing liability would not "create an undue burden upon [the defendant's] freedom of action." ${ }^{\text {33 }} \mathrm{By}$ making these points, the court came close to addressing privity concerns. Like courts considering liability for negligent performance of accounting services, the court emphasized that the laboratory knew of the plaintiff, and was aware that its negligence could lead to loss of employment opportunities and reputational damage. The court then concluded that imposing a duty of rea-

* Surprisingly, none of the opinions finding liability explicitly addressed possible arguments against liability. This makes it more difficult to determine why privity, which proved determinative in other cases, did not bar recovery. However, each of the courts considers the foreseeability of the harm and the certain nature of the liability, two concerns motivating the privity requirement.

19 588 S2d 175 (La App 1991).

so Id at 176.

${ }^{51}$ Lewis, 588 S2d 167, 170 (La App 1991).

52 Id, citing La Civ Code Ann §§ 2315-16 (West 1979).

${ }^{53}$ Lewis, $588 \mathrm{~S} 2 \mathrm{~d}$ at 170. 
sonable care would "foster a greater sense of responsibility within [the laboratory] to perform its drug testing services in a skillful and competent manner. ${ }^{254}$

In a subsequent Louisiana case, Nehrenz $v$ Dunn, the court found liability based on "simple negligence," applying the same Louisiana statute used in Lewis. ${ }^{55}$ The court did not, however, engage in an in-depth analysis of the policies for and against liability. Instead, the court relied upon Louisiana's negligence statute, cited Lewis for the proposition that negligence has been imposed in Louisiana, and concluded that "[t]his duty encompasses the injuries which Nehrenz allegedly sustained."

In the most recent case, Stinson o Physicians Immediate Care, Ltd, the Appellate Court of Mlinois used a balancing test to determine whether the laboratory stood in such a relationship to the plaintiff that it had a duty to act reasonably for his protection. The court considered and rejected the argument that no duty could exist without contractual privity. ${ }^{57}$ The court drew an analogy between the duty an attorney owes to a third-party beneficiary of a contract and the duty a testing laboratory owes to the subject of a drug test. ${ }^{58}$ The court then concluded that "there is a close relationship between a plaintiff and a defendant which had a contract with the plaintiff's employer if it is reasonably foreseeable that the plaintiff will be harmed if the defendant negligently reports test results to the employer. ${ }^{159}$ The court emphasized that, although the plaintiff could not recover on the basis of a contractual duty, "[t]here need not be a contract between the plaintiff and the defendant for the defendant to owe a tort duty." $" 60$

The court's balancing test included "the foreseeability of the injury, the likelihood of the injury, the magnitude of the burden of guarding against it and the consequences of placing that burden on the defendant," and concluded that a duty was appropriate. ${ }^{61}$ In reaching this conclusion, the court pointed out that the plaintiff's injury was not only foreseeable, but "a virtual cer-

$\rightarrow$ Id.

Nehrenz, 593 S2d 915, 918 (La App 1992).

$"$ Id. The court also noted that it had "found a cause of action based on negligence in Lewis...." Id at 917.

${ }^{57} 269$ Ill App 3d 659, 646 NE2d 930, 933-34 (1995).

w* Id at 933. The court did not explicitly consider whether the tested worker was the intended beneficiary of the contract between the employer and the laboratory, and cases considering the question have decided that the test subject is not the primary beneficiary. See, for example, Devine $v$ Roche Biomedical Laboratories, 659 A2d 868, 870 (Me 1995).

Stinson, 646 NE2d at 933.

(x) Id.

IId. 
tainty" in the event of a false positive test result, and that the likelihood was great. ${ }^{62}$ The court found the burden on the defendant of a duty to be negligible because the laboratory "is in the best position to guard against the injury, as it is solely responsible for the performance of the testing and the quality control process," and "is better able to bear the burden financially than the individual wrongly maligned by a false positive report." ${ }^{63}$

Although these courts each take a slightly different approach to the issue, all of them reach the correct result. Their arguments, while persuasive, could pay more attention to efficiency and precedent. As will be discussed more fully below, other courts deny recovery to victims of false positives because the laboratory is not in privity with the worker and the harm is purely economic. The response to these courts' concerns can be found in the analogy to accountants' liability, which will be considered in Part III.

\section{B. Cases Denying Liability}

Some cases deny liability for the same type of simple negligence claims with which the plaintiffs in Stinson, Elliott, $\mathrm{Ne}$ hrenz, and Lewis succeeded. Others deny liability because the plaintiff pleaded a cause of action in a novel way. Such claims include intentional and strict liability torts, contract claims, and "failure to warn" claims. Intentional torts, such as intentional infliction of emotional distress and intentional interference with contractual or economic advantage, fail unless plaintiffs can prove intentional conduct. Strict liability actions such as product liability, malpractice, and breach of contract all fail because courts reject their applicability in the drug testing context. Failure to warn claims fail because courts are unwilling to impose such an amorphous duty.

At first glance, this might suggest that plaintiffs need simply plead their cases carefully. In several cases, however, courts have effectively converted simple negligence actions into claims for intentional torts, stating that the cause of action is nothing more than a claim of interference with contractual advantage, and stating that the cause of action is not recognized in the court's state. Indeed, most states require intentional conduct for interference with contractual advantage or infliction of emotional distress. The following discussion of the cases in which plaintiffs' claims have been denied will explain why the unusual causes of

\footnotetext{
${ }^{62}$ Id.

"Id at 934.
} 
action failed and will note the absence of clear explanations for the courts' failure to recognize claims for simple negligence.

1. Product liability.

In DiTomaso v Electronic Data Systems, several security guards attempted to sue a drug testing laboratory, as a product manufacturer, for negligently designing a urinalysis test and for breaching implied and express warranties. ${ }^{64}$ The "product" was not the machinery used to run the test, but the testing procedure and results, which were allegedly defective because they rendered false positive results and because they revealed the use of drugs rather than the impairment of faculties by drugs. ${ }^{65}$ The court questioned the characterization of the test as a "product," but ruled instead on the grounds that the plaintiffs had failed to produce any evidence that the test could or did result in a false positive. The court noted that, in contrast, there had been expert testimony to the effect that the laboratory had never had a false positive, and that the series of three increasingly sophisticated tests it used to identify and verify positive results had never been documented to produce a false positive in the scientific literature. ${ }^{66}$

Since DiTomaso did not explicitly decide whether a test result could be a "defective product" for which a testing laboratory could be held strictly liable, it does not provide precedent for other courts. However, it is unlikely that other courts will accept this rationale for liability because there is no defective "product" for which a "manufacturer" could be held liable in the typical case. If a plaintiff could show that the equipment used to perform the test was defective, she might recover from the equipment's manufacturer, although even then she might have to show physical harm. ${ }^{67}$ In contrast, the typical drug testing plaintiff wants to

1988 US Dist LEXIS 16806, *1 (E D Mich). If the laboratory were a manufacturer, it would have a duty under Michigan law to warn foreseeable users of the dangers inherent in its product. Id at*4.

${ }^{\infty}$ Id at $* 1$.

* Id at *5-7. The court also sidestepped the issue of whether the test could be considered a "good" or "product" for purposes of a warranty claim, holding instead that the Uniform Commercial Code only applies between buyers and sellers, not between manufacturers and third party consumers. Id at $* 7$.

"7 The Restatement (Second) of Torts contains the following entry on product liability: \$ 402A Special Liability of Seller of Product for Physical Harm to User or Consumer

One who sells any product in a defective condition unreasonably dangerous to the user or consumer or to his property is subject to liability for physical harm thereby caused to the ultimate user or consumer, or to his property ....

Comment $\mathrm{d}$ of the section includes examples of products, which include "an automobile, a 
recover for negligent provision of a service, not negligent design or construction of a physical object, so her claim does not fall within product liability.

Courts are unlikely to hold laboratories liable under this theory, and the consequences of doing so would be inferior to holding them liable under a negligence theory. While product liability would have the advantage of compensating workers, even in cases where the laboratory was not at fault, the imperfect analogy might lead to disputes over whether a part of the testing service, say the "chain of command" for testing records, constituted part of the "product" or an extraneous service. General negligence liability will avoid this problem. Furthermore, extending product liability to drug testing services would open the door to imposing strict liability for all kinds of services; the carefully drawn exceptions to negligence would swallow the rule. Therefore, despite the superficial attractiveness of strict product liability, courts should limit liability to situations in which the plaintiff can prove negligence.

\section{Defamation.}

In Willis $v$ Roche Biomedical Laboratories, Inc, the plaintiff alleged that the defendant, a testing lab, had defamed him by communicating false positive test results to his employer. ${ }^{68}$ The Fifth Circuit, applying Texas law, held that a qualified privilege attached to a testing laboratory's communication of false positive results to an employer, and thus a worker must show express or implied malice to recover. ${ }^{69}$ The need to recognize a qualified privilege in this context seems clear; without it, testing laboratories would be strictly liable for false positives. ${ }^{70}$ In some respects, strict liability would be superior to negligence liability in the drug testing context, because proving negligence will be difficult

tire, an airplane, a grinding wheel, a water heater, a gas stove, a power tool, a riveting machine, a chair, and an insecticide." Restatement (Second) of Torts $\S 402 A$ (1965).

6s $61 \mathrm{F3d} 313$ (5th Cir 1995).

${ }^{69}$ Id at 316-17.

70 The Restatement (Second) of Torts provides two exceptions to the general rule of strict liability for the publication of defamatory matter. The first, the absolute privilege, does not apply. The second, conditional (or qualified) privilege, does. Section 595 provides that a publication is privileged if it "affects a sufficiently important interest" of the recipient, and if the publisher is under a legal duty to publish the information or if its publication is consistent with standards of decent conduct. In deciding whether something constitutes decent conduct, an important consideration is whether the information is provided in response to a request or is volunteered; responding to a request generally constitutes decent conduct. Restatement (Second) of Torts $\$ 595$ (1977). According to $\S 593$, a publisher will not be held liable where the occasion makes the publication privileged, and where that privilege is not abused. 
and costly, and workers will not be compensated under negligence when the false positive result is not caused by laboratory negligence. However, this would be an unprecedented step beyond current law, which limits strict liability to certain unique situations, most of which involve physical harm. ${ }^{71}$ Thus, defamation is an inappropriate remedy, because it imposes strict liability for behavior that is typically subject to a duty of reasonable care, and because it prevents a complete analysis of the policy issues for and against holding testing laboratories liable.

\section{Infliction of economic harm.}

Typically, tort claims involve physical injury, with economic or emotional harm as a consequence of the physical injury. In fact, the common law traditionally did not allow damages for purely economic harm without proof of physical injury. ${ }^{72}$ Today, courts allow damages for purely economic harm in many circumstances, ${ }^{73}$ but the basic common law rule remains unchanged. The common law does recognize the tort of intentional interference with a contractual right, and one court upheld a lower court ruling that a testing laboratory had failed to negate a claim of "willful and intentional interference with the conditional offer of employment."74

However, the recognition of intentional interference with contractual rights does not help the typical victim of a false positive who suffers because of the testing laboratory's negligence and finds herself within the scope of the common law rule against purely economic damages. In Herbert $v$ Placid Refining Co, the Louisiana Court of Appeals held that the plaintiff's claim for simple negligence was essentially a claim for negligent interference with contractual rights, whereas Louisiana required intentional interference. ${ }^{75}$ Thus, by recharacterizing the plaintiff's claim as one requiring intentional action, the court made liability impossible. ${ }^{76}$

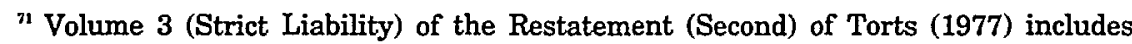
trespass by livestock ( $\S \S 504-05$ ); harm, other than trespass, done by wild animals ( $\S$ 506-18); and abnormally dangerous activities (\$\$ 519-24A). Strict liability also includes defamation and product liability.

${ }^{72}$ Ann O'Brien, Note, Limited Recovery Rule as a Dam: Preventing a Flood of Litigation for Negligent Infliction of Pure Economic Loss, 31 Ariz L Rev 959, 959-61 (1989), citing Robins Dry Dock \& Repair Co v Flint, 275 US 303 (1927).

${ }^{73}$ In fact, a minority of states now allow recovery in negligence for foreseeable economic losses. O'Brien, Note, 31 Ariz L Rev at 959-61 (cited in note 72). See also Part III.

"SmithKline Beecham Corp v Doe, 903 SW2d 347, 355 (Tex 1995).

${ }^{\pi 5} 564$ S2d 371, 374 (La App 1990).

io The court's reasons for doing so were unclear; Part III will argue that the court 


\section{Breach of contractual duty of reasonable care.}

Some workers have sued testing laboratories for breach of a contractual duty of reasonable care and argued that the laboratory owes the same duty of care to the worker that it does to the employer. Generally, contracting parties only acquire a duty to one another; the parties have no duty to third parties who might be affected by the performance of their contractual obligations. ${ }^{77}$ However, the law provides two important exceptions to this rule: the foreseeable reliance exception, and the exception for third party beneficiaries.

Under the reliance exception, a contracting party whose conduct induces reasonable reliance by a third party may be liable if that third party "changed her position" in reliance upon that conduct. $^{78}$ No case has addressed the reliance exception in the drug testing context. ${ }^{79}$ In practice, plaintiffs rely on the third party beneficiary exception. Under this exception, a contracting party acquires a duty of reasonable care toward a noncontracting party who is the intended beneficiary of the contract. ${ }^{80}$ However, this exception requires that the contracting parties intend, at the time they contract, primarily to benefit the third party. This element is questionable in the employer drug testing situation. The employer's purpose in arranging for the

implicitly rejected the negligence claim because it seemed inconsistent with traditional rules against recovery for economic harm without a relationship of privity. Since simple negligence liability and the traditional duty balancing test are available in the common law of every state, the court probably rejected that analysis because of the traditional refusal to award purely economic damages to parties not in privity. This traditional principle has steadily eroded over time and should not be applied in the drug testing context. See text accompanying notes 108-13.

" Contracting parties may be held liable for physical injuries to third parties, but generally face no liability for negligence resulting in purely economic harm. James M. Dente, Negligence Liability to All Foreseeable Parties for Pure Economic Harm: The Final Assault upon the Citadel, 21 Wake Forest L Rev 587, 588 (1986).

${ }^{73}$ See, for example, Corbin on Contracts § 779B (1951 \& Supp 1996); Dente, 21 Wake Forest $L$ Rev at 591 (cited in note 77), citing cases.

${ }^{79}$ Hypothetically, though, a worker could claim that she relied on the belief that the testing laboratory would use reasonable care when she decided to take a drug test. However, she would have difficulty showing that her belief caused her to change her position, since her only alternative would have been to quit her job. In some cases, however, this might be a plausible argument, particularly where the demand for a worker's services is high and she foregoes other opportunities by applying to this employer. In such a case, a false positive causes not only the loss of the current job, but a substantial reduction in future job prospects. If a worker feared the risk of permanent unemployment enough to cause her to give up her current job rather than to take a drug test without adequate safeguards, she might succeed in arguing that she "changed her position" in reliance on her belief that reasonable care would be taken, simply by not quitting. The number of situations in which this argument could apply seems small, however, and plaintiffs should not have to fit within this narrow class in order to recover.

${ }^{80}$ See generally Corbin on Contracts $\S \S 772,776-79$ (cited in note 78). 
test is to increase worker productivity and to avoid lawsuits from clients or other workers who could be hurt as a result of on-thejob drug use. Although workers whose tests come out negative certainly receive a reputational benefit from the test results, and although a worker who tests positive can be rehabilitated, these benefits to the worker are at best a bonus to the employer, and do not make the contract between the employer and the testing laboratory one that confers its primary benefit upon the worker. Thus, it is not surprising that in Devine $v$ Roche Biomedical Laboratories, the Supreme Judicial Court of Maine held that a worker was not a third party beneficiary of a contract between the employer and the testing laboratory. ${ }^{81}$

Although a contractual remedy for workers would achieve the same goals as negligence liability, courts are much less likely to grant such a remedy. The exceptions to the privity requirement in contract are well established and thoroughly developed by the courts. Like product liability and defamation, the exceptions to contractual privity have been carefully designed for application to a limited number of situations. In contrast, the duty test for negligence liability remains flexible, allowing courts to consider policy objectives and adapt to new situations. For these reasons, courts should prefer a tort duty to a contractual duty for drug testing laboratories.

\section{Duty to warn.}

As explained above, many of the tests used to detect drug use may mistake legal substances, such as foods or nonprescription medicines, for illegal drugs. ${ }^{82}$ Based on this fact, and the possibility that employers might overestimate the accuracy of drug tests, one plaintiff argued that the testing laboratory had a duty to warn her, or her employer, that ingestion of poppy seeds could cause a false positive test result. In SmithKline Beecham Corp $v$ Doe, the Supreme Court of Texas rejected her argument, finding that no duty to warn existed with respect to either the plaintiff or her employer..$^{83}$ An earlier case, Caputo $v$ Compuchem Laboratories, Inc, also refused, on the facts, to hold a testing laboratory liable under a duty-to-warn theory where it produced a "weak" positive result and, instead of retesting the specimen with more sophisticated equipment, reported the result to the

${ }^{* 1} 659$ A2d 868, 870 (Me 1995). The court stated in a footnote that the plaintiff would have a tort claim, but that his failure to produce an issue of material fact "left Devine's third party beneficiary claim as his last hope against the laboratories." Id at $871 \mathrm{n} 2$.

${ }^{12} 2$ See note 20.

${ }^{10} 903$ SW2d 347, 354 (Tex 1995). 
employer. ${ }^{84}$ Both of these cases, however, have unusual facts that suggest that they might not preclude a court from finding a duty to warn in future cases. ${ }^{85}$

The SmithKline court rejected the plaintiff's argument that the lab had a duty to warn based on its awareness of the danger of false positives. The plaintiff had cited a prior case, Buchanan $v$ Rose ${ }^{86}$ in which a bridge broke down as a truck driver drove over it, due not to any negligence on the driver's part, but to the bridge's deteriorated condition. A witness driving behind the truck saw the bridge break under the weight of the truck's rear wheels. The witness then managed to cross the bridge and overtake the truck driver. The witness notified the driver of the dangerous situation he had created by his passage and suggested he post a warning; the truck driver refused to do so. ${ }^{87}$ The Supreme Court of Texas held that the truck driver had no duty to post a warning because he did not negligently create the dangerous situation. ${ }^{88}$ The SmithKline plaintiff argued that the testing laboratory should be liable because, unlike the truck driver, it had "created a dangerous situation-namely, the possibility that she would test positive when she had not used any drugs."

In applying the precedent to SmithKline, the court observed that, although the truck's passage made the bridge's defects ap-

ss 1994 US Dist LEXIS 2191, *12 (E D Pa), affd without opinion, 37 F3d 1485 (3d Cir 1994), cert denied, 115 S Ct 733 (1995).

ss In SmithKline Beecham, the plaintiff initially tried to explain away the positive result by stating that she had taken her roommate's Vicodin, a fact she had not disclosed before the test. Prior to the test, she had been informed that, if she did not disclose any medications she had been taking before the test, she could be rejected for employment. As revealed by these facts, the plaintiff was unsympathetic.

The facts played a similar role in Caputo, where the court emphasized that the results of the test were communicated to a company doctor rather than a layperson:

Moreover, even if we were to agree that the defendant owed plaintiff some sort of duty to assure that the employer understood that the numerical result was a "weak" positive and, therefore, might not indicate substance abuse, we conclude that the fact that the report was transmitted to an employee at Air Products who bore the title "doctor" discharges any such hypothetical duty in that, as a matter of law, a reasonably prudent testing laboratory could thereby assume that the test results would be appropriately reviewed by knowledgeable medical personnel.

Caputo, 1994 US Dist LEXIS 2191 at *10. Many employers and laboratories choose to have results reviewed by a physician if the employer does not have one in-house. See note 47.

${ }^{86} 138$ Tex 390, 159 SW2d 109 (1942).

${ }^{67}$ SmithKline, 903 SW2d at 353, citing Buchanan, 159 SW2d 109.

${ }^{88}$ Buchanan, 159 SW2d at 110-11. This version of the duty to prevent injury to others is unusual in its insistence that the dangerous situation be created negligently. The Restatement (Second) of Torts imposes this duty whether the defendant has created the situation innocently or negligently. Restatement (Second) of Torts \$ 321 (1965).

${ }^{29}$ SmithKline, 903 SW2d at 353. 
parent, the act creating the dangerous situation was someone's failure to maintain the bridge properly. The court then analogized drug testing laboratories to the truck driver, stating that a testing laboratory, like the truck driver, is a "mere bystander who did not create the dangerous situation," because it is the employer who requests the test and determines how it will be used..$^{90}$ Just as the truck driver could have prevented further injury with a warning, the laboratory could have prevented the firing by giving the employer advice about the reliability of the test. But in both cases, according to the court, the corrective measure was optional, beyond the call of duty. ${ }^{91}$

The court's use of the analogy is questionable, however. The plaintiff in SmithKline could argue that after "creating a dangerous situation" by negligently conveying a false positive test result, the defendant had an opportunity to avoid injury by telling plaintiff's employer that the result could have been caused by ingestion of poppy seeds. In practice, this warning would probably occur simultaneously with communication of results, but the act of mitigating the potential injury by warning that the result might not reflect drug use could be seen in some cases as a measure taken to mitigate the results of previous negligence.

Typically, though, "false positives" based on ingestion of substances, like poppy seeds, whose metabolites confuse the drug test, do not arise as a result of the testing laboratory's negligence in handling specimens or analyzing results. Most tests currently in use will confuse certain substances with illegal drugs even under ideal testing circumstances. Thus, a warning to the employer or worker is not a measure taken to mitigate past negligence, but an attempt to provide relevant information.

\section{Simple negligence.}

The court in Willis also considered simple negligence liability and denied recovery on the basis of an "Erie prediction" of state law; the court did not offer an independent analysis of the issues involved. ${ }^{92}$ The plaintiff was tested for drugs at the request of his

"Id.

st Id.

${ }^{52}$ Willis, 61 F3d at 315-16, citing SmithKline, 903 SW2d 347. This opinion superseded a previous opinion finding liability, which was denounced in SmithKline as a faulty Erie prediction for two reasons. First, the court relied upon a Texas Court of Appeals decision over which the Supreme Court of Texas had granted certiorari, suggesting that the opinion's statement of Texas law might not be accurate. Second, the decision considered the question of "duty to warn," rather than negligence liability, and explicitly refrained from deciding the negligence question. SmithKline, 903 SW2d at 352. 
employer, DuPont, and received a false positive test result. Between early August, 1990, when defendant Roche gave DuPont the result, and November 2, 1990, when Roche informed DuPont that the result was a false positive, the plaintiff was placed on restrictive work duty, sent to a physician, required to attend counseling, and required to receive follow-up tests. ${ }^{93}$

In analyzing the question whether Roche owed the plaintiff a duty to use reasonable care in handling his test, the court relied upon SmithKline for its holding that no duty of care toward the worker in this context exists in Texas. ${ }^{94}$ Although the Fifth Circuit had previously found that a duty did exist, it withdrew that earlier and more detailed opinion and replaced it with a cursory finding of no liability after the Supreme Court of Texas in SmithKline denounced its previous ruling as an unsound Erie prediction. $^{95}$

While the second Willis opinion provides little analysis, and no Texas state court has considered the issue of simple negligence, the Texas Supreme Court's caustic rejection of the Fifth Circuit's initial opinion strongly suggests that no duty of reasonable care exists in Texas.

Although the Texas Supreme Court claimed not to consider whether a general duty of care exists, it followed its jibe at the Willis opinion with a brief analysis of cases involving negligent performance of polygraph tests. The court conceded that a few courts had imposed a duty of reasonable care on polygraph testers for foreseeable effects on plaintiffs' employment opportunities, but found the opinion in Hall $v$ UPS ${ }^{96}$ a New York Court of Appeals decision finding no duty, authoritative. It dismissed a contrary holding by the Arkansas Supreme Court, the only other court of last resort to consider the issue, because "the grounds [were] not clear.".97

${ }^{s 3}$ Willis, 61 F3d at 314.

${ }^{4}$ Id at 316.

s 'And Willis is based solely, and erroneously, on the court of appeals' decision in the case now before us. The issues in the two cases are simply not the same. (Curiously, the Fifth Circuit did not regard this Court's having agreed to review the court of appeals' decision as relevant in evaluating its precedential value.)" SmithKline, 903 SW2d at 352 (citation omitted).

${ }^{96} 76$ NY2d 27, 556 NYS2d 21, 26 (1990).

${ }^{9}$ SmithKline, $903 \mathrm{SW} 2 \mathrm{~d}$ at 352 . The court's insistence on looking only to courts of last resort seems odd in the context of polygraph testing, which, like drug testing, remains an unsettled legal issue. As the court admitted, a number of lower courts have considered the issue, the majority coming out in favor of polygraph testing. Id, citing Ellis $v$ Buckley, 790 P2d 875, 877 (Colo Ct App 1989); Lawson v Howmet Aluminum Corp, 449 NE2d 1172, 1177 (Ind Ct App 1983); Zampatori v United Parcel Service, 125 Misc2d 405, 479 NYS2d 470, 473-74 (NY Sup Ct 1984). In addition, the Hall opinion on which the 


\section{PRIVITY: INAPPROPRIATE FOR ACCOUNTANTS AND INAPPROPRIATE FOR DRUG TESTING LABORATORIES}

Part I of this Comment argued that absent any concerns based on precedent, drug testing laboratories should be held liable for their negligence. Part II demonstrated that courts did not always find liability, but they did not clearly articulate the objections to liability. This Part will examine accountants' liability cases to identify a possible concern-the traditional rules against liability for purely economic loss except in privity of contract-and suggest that these rules need not apply in every case. It will argue that, although courts should not ignore these concerns in the drug testing context, they should respond to them by looking at the justifications for the traditional rule. Because those justifications do not apply to drug testing laboratories, liability for purely economic harm in the absence of privity is appropriate.

Accountants' liability cases, like drug testing cases, involve issues of privity and pure economic or emotional loss and provide persuasive authority. Like drug testing laboratories, accountants provide services with incidental benefits to parties other than the companies with whom they contract. ${ }^{98}$ In fact, accounting firms often have no idea who will be relying on their reports, which they perform based on analysis of the audited company and provide directly to the company. As in the case of drug testing, the harm caused by a negligent audit report is purely economic, and may often result from negligence rather than intentional misrepresentation. ${ }^{99}$ Thus, accountants' liability cases are strongly analogous to drug testing laboratory liability cases. As the following discussion demonstrates, courts will impose liability for purely economic loss when they are convinced that unlimited or unforeseeable liability will not result.

In the early case of Ultramares Corp $v$ Touche, New York's highest court established a rule requiring contractual privity for accountants' liability. ${ }^{100}$ This remains the law today in New York

court relied emphasized that federal legislation, the Federal Worker Polygraph Protection Act, regulates polygraph testing. According to the Hall court, the existence of such regulation suggests that no additional state protections should be afforded. Hall, $555 \mathrm{NE} 2 \mathrm{~d}$ at 278 (finding that federal polygraph testing legislation "greatly diminishes the strength of the arguments for recognizing a new tort remedy at the state level").

s: The audit report with an "unqualified opinion ... gives the financial statements the credibility that clients and third parties seek through the audit process." Ronald A. Schy, Privity and Accountants' Liability, 16 Sec Reg L J 54, 56 (1988).

9 Id.

255 NY 170, 174 NE 441, 444 (1931) (Cardozo opinion), cited in Schy, 16 Sec Reg L $\mathrm{J}$ at 58 (cited in note 98 ). 
and other states. ${ }^{101} \mathrm{~A}$ more recent case stated that liability in the accounting context for parties not in privity requires knowledge by the accounting firm of the purpose to which the report would be put, that the purpose include intended reliance by known third parties, and that the accountants conduct themselves in such a way that reveals their awareness of the parties' reliance. ${ }^{102}$ California and several other states have embraced a different standard, however, allowing damages to all "reasonably foreseeable" users of audited financial statements. ${ }^{103}$

One major element separates accountants' liability plaintiffs from victims of inaccurate drug tests: investors rely upon audited financial statements. ${ }^{104}$ Should this factor be important? As a legal matter, it allows plaintiffs to use the "foreseeable reliance" exception to privity in contract claims. However, courts should not require reliance where liability is otherwise limited. The development of accountants' liability law illustrates that courts will not impose liability for unforeseeable plaintiffs or unforeseeable harms, but will impose liability for harm that accountants could reasonably expect to cause by their negligence. Since drug testing laboratories are perfectly aware of the consequences of their negligence, the fact that the victim's employer relies, instead of the worker, should not bar recovery. Courts' willingness to hold accountants liable for their errors despite the economic nature of the harm provides a useful basis for courts to do the same in the drug testing context if they are satisfied that the resulting liability will not be unlimited or unreasonable.

\section{A. Brief History of Privity}

The "Ultramares rule" of no recovery for economic loss without contractual privity was based on a fear of unlimited liability disproportionate to the harm caused. ${ }^{105}$ One aspect of the contractual relationship is that the parties will be able to contract around liability by defining duties and limitations on penalties

\footnotetext{
${ }^{101}$ See, for example, Schy, 16 Sec Reg L J at 58 (cited in note 98) (citing cases from seven jurisdictions).

${ }^{102}$ Credit Alliance Corp $v$ Arthur Andersen \& Co, 65 NY2d 536, 493 NYS2d 435, 443 (1985), cited in Schy, 16 Sec Reg L J at 59 (cited in note 98).

${ }^{103}$ Schy, 16 Sec Reg L J at 59 (cited in note 98), citing $H$. Rosenblum, Inc $v$ Adler, 93 NJ 324, 461 A2d 138 (1983); Citizens State Bank v Timm, Schmidt \& Co, 113 Wis 2d 376, 335 NW2d 351, 367 (1983); Bradford Sec Processing Serv v Plaza Bank \& Trust, 653 P2d 188, 190-91 (Okla 1982); International Mortgage Co $v$ John P Butler Accountancy Corp, 177 Cal App 3d 806, 223 Cal Rptr 218 (1986).

${ }^{104}$ Schy, 16 Sec Reg L J at 56-57 (cited in note 98).

${ }^{105}$ Ultramares, $174 \mathrm{NE}$ at 444.
} 
for breach. In addition, the rule in Hadley $v$ Baxendale ${ }^{106}$ limits recovery to damages that were reasonably foreseeable to the defendant. These factors substantially limit the parties' liability; both unforeseen plaintiffs and unforeseen damages will be disallowed.

This, in turn, allows for pricing commensurate with potential liability. The price does not take into account possible consequences for third parties, but that result makes sense when the possible third parties are an unidentified mass, with unidentified harms, because the price increase for such massive and uncertain liability would probably exceed the amount of damage actually caused and compensable. This is especially apparent when one considers that a contract can have consequences of which the parties to the contract, and any potentially affected third parties, are unaware. A rule of unlimited liability would force contracting parties, when determining the contract price, to consider the possibility that the contract might cause a remote third party to suffer a loss. It is this concern for remoteness that has motivated privity law in the accountants' liability context since Ultramares; Justice Cardozo believed that a rule imposing "liability in an indeterminate amount for an indeterminate time to an indeterminate class" was "so extreme as to enkindle doubt whether a flaw may not exist in the implication of a duty that exposes to these consequences." 107

But these concerns do not require absolute privity. Rather they require conditions in which a contractor is aware of the kind of harms (so she can take appropriate precautions) and amount of potential damages (so she can price accurately) for which she will be liable. Therefore the New York rule, the strongest in the accountants' liability context, requires knowledge by the accountant of the parties to whom he will be liable, and the purposes for which his work will be used, with conduct of the accountant used to demonstrate knowledge about the party's reliance. $^{108}$

B. Concerns Behind Privity Do Not Preclude Liability in the Drug Testing Context

Even under New York's strict test, ${ }^{109}$ the considerations that motivate the privity rule do not apply here. Unlike accountants

\footnotetext{
${ }^{100} 156$ Eng Rep 145 (1854).

107 Ultramares, $174 \mathrm{NE}$ at 444.

${ }^{100}$ Schy, 16 Sec Reg L J at 58 (cited in note 98).

${ }^{109}$ See note 100 and accompanying text.
} 
who, in the absence of a privity rule, could be liable to an unlimited number of people, drug testing laboratories have complete control over the number of plaintiffs who may successfully sue them: the number of employers contracted with, plus the number of subjects tested. The kinds of harm caused by false positives are apparent and are frequently and thoroughly discussed in newspapers as well as medical journals. ${ }^{110}$

The only factor differentiating drug testing laboratories from accountants is the possibility that a testing laboratory may not be aware of the specific purpose of the test and the degree to which the employer intends to rely upon it. This factor could substantially influence the damages for which a laboratory might be held liable. But, because the party relying is also the party dealing directly with the testing laboratory, obtaining that kind of information should not be difficult. Laboratories could easily charge different prices for pre-employment screenings than for tests of current workers, based on the availability of selfpublication or wrongful termination damages for those already employed. The fact that the party relying upon the test is not the one likely to incur substantial damages and to ultimately sue actually eases this burden on the testing laboratory, because it makes estimating potential liability easier. Thus, abandoning the privity requirement for drug testing laboratories performing tests on workers will not lead to the kind of unlimited liability Justice Cardozo feared.

Furthermore, liability for drug testing laboratories has a significant factor that is absent in the accountants' liability context. Auditors are not the cheapest cost avoiders of harm, ${ }^{111}$ whereas drug testing laboratories are. This is because, in the accounting context, the audited company can avoid harm most cheaply by preparing accurate financial statements. ${ }^{112}$ In contrast, employers can do nothing to protect against false positives, while laboratories can do everything.

Although only a few courts so far have recognized a cause of action for negligent infliction of pure economic loss, the availability of purely economic damages in the accountants' liability scenario suggests that even courts that adhere to the rule bend it in appropriate circumstances. They apparently do so because accountants' liability does not present the kind of problem that the rule was designed to avoid. Along with the privity requirement,

\footnotetext{
${ }^{10}$ See, for example, Spolar, Wash Post at A14 (cited in note 4).

"'Schy, 16 Sec Reg L J at 63 (cited in note 98).

${ }^{112}$ Id.
} 
limitations on purely economic losses are intended to prevent unlimited liability. ${ }^{113}$ Again, the analogy to accountants' liability suggests that the economic nature of the harm to false positive victims poses no problems in this context.

\section{CONCLUSION}

Although courts addressing whether laboratories should be held liable provide little guidance to commentators and other courts, this Comment concludes that two sets of factors influence their decisions. Courts finding liability have focused on a set of policy factors that includes a concern for fairness to workers and a desire for the efficient administration of drug tests. They implement their concerns using the policy-oriented duty balancing test. Unfortunately, none of the courts applying the balancing test explicitly addresses concerns about purely economic harm or the privity rule, both of which seem to be motivating decisions against liability.

Courts denying liability in similar contexts focus on privity and the lack of physical injury. Because of these tort principles, courts have not found the simple balancing test appropriate, and instead have forced plaintiffs to demonstrate intentional conduct. Although some decisions make the rule against purely economic loss for non-privity plaintiffs seem inflexible, the imposition of liability for purely economic loss on accountants demonstrates that it is not. Instead, the rule consists of a policy choice designed to promote fairness and efficiency, just like the policy choices implemented in Elliott and Stinson. In this case, fairness and efficiency are met by the removal of the standard rule. Drug testing laboratories do not need the protection of the rule because they do not face unlimited liability to uncertain plaintiffs for unforeseeable injuries. Once the barrier of the rule against purely economic loss without privity is removed, courts have every reason to apply the duty balancing test and hold testing laboratories liable for their negligence. By doing so, courts will ensure a fair and efficient solution to a serious workplace problem.

\footnotetext{
${ }^{113}$ O'Brien, Note, 31 Ariz L Rev at 960 (cited in note 72), citing Cattle $v$ Stockton Waterworks Co, 10 LR-QB 453 (1875).
} 
. 